\title{
STUDI DESKRIPTIF PERAWATAN LUKA PASIEN DENGAN INFEKSI POST OPERASI LAPAROTOMI DI KABUPATEN SUMEDANG
}

\author{
Ressa Andriyani Utami ${ }^{1}$ ), Cecep Eli Kosasih ${ }^{2}$ ), Anastasia Anna ${ }^{2}$ ) \\ ${ }^{1}$ ) Dosen Akademi Keperawatan RS Husada, Jakarta, 10730, Indonesia \\ $\left.{ }^{2}\right)$ F.Kep, Universitas Padjadjaran, Kampus Jatinangor, 45363, Indonesia \\ E-mail : ressa.andriyani.utami@gmail.com
}

\begin{abstract}
ABSTRAK
Laparotomi merupakan tindakan pembedahan pada area abdominal untuk mengatasi masalah kesehatan. Risiko infesi dapat terjadi akibat perawatan luka yang tidak adekuat pasca operasi. Penelitian ini menggunakan pendekatan deskriptif untuk mengetahui gambaran pelaksanaan perawatan luka pasien post operasi laparotomi di Kabupaten Sumedang. Sampel penelitian adalah 60 responden, diambil dengan total sampling. Pengukuran pelaksanaan perawatan luka digunakan menggunakan instrumen SOP Pelaksanaan Perawatan Luka Depkes RI menggunakan metode observasi non partisipasif. Hasil penelitian menunjukkan tahap pengkajian yang dilakukan oleh perawat dilaksanakan $44 \%$ adekuat, 35\% tahap analisa data adekuat, $48 \%$ perencanaan keperawatan adekuat , 32\% implementasi adekuat, dan $80 \%$ tahap evaluasi dan dokumentasi adekuat. Penelitian ini merekomendasikan untuk perawat untuk melakukan perawatan luka sesuai SOP dan pihak Rumah Sakit menyediakan fasilitas yang memadai untuk melakukan tindakan keperawatan.
\end{abstract}

Kata kunci : infeksi nosokomial, laparotomi, pasca operasi, perawatan luka

\begin{abstract}
Laparotomy is a surgical procedure in the abdominal area to overcome health problems. The risk of infection can occur due to inadequate postoperative wound care. This study used a descriptive approach to determine the description of the implementation of wound care for postoperative laparotomy patients in Sumedang District. The study sample was 60 respondents, taken by random sampling. Measuring the implementation of wound care was used using the SOP of the Ministry of Health's Republic of Indonesia Health Care Implementation Instrument using a non-participatory observation method. The results showed that the stage of the study carried out by nurses was $44 \%$ adequate, $35 \%$ of the data analysis stage was adequate, $48 \%$ of adequate nursing planning, $32 \%$ of adequate implementation, and $80 \%$ of the evaluation and documentation stages were adequate.

. This study recommends that nurses do wound care according to the SOP and the Hospital provides adequate facilities to carry out nursing actions.
\end{abstract}

Keywords: nosocomial infections, laparotomy, postoperative, wound care

JKH/ Volume 3/ Nomor 1/Januari 2019 (ISSN: 2548-1843, EISSN: 2621-8704) 


\section{PENDAHULUAN}

Pelayanan keperawatan di Rumah Sakit merupakan salah jenis pelayanan kuratif professional utama yang diselenggarakan untuk memenuhi kebutuhan serta tuntutan masyarakat sebagai pengguna jasa kesehatan. Pelayanan keperawatan dilakukan sebagai upaya meningkatkan derajat kesehatan, mencegah penyakit, penyembuhan, pemulihan dan pemeliharaan kesehatan yang dilakukan sesuai dengan wewenang, tanggung jawab dan etika profesi keperawatan. (Awad et al, 2009).

Permasalahan yang sering dihadapi pada post operasi adalah terjadinya komplikasi pada luka operasi terutama infeksi, yaitu suatu keadaan masuknya kuman, menetap dan multiplikasi. Infeksi Luka Operasi (ILO) merupakan kondisi yang ditandai dengan adanya pus, inflamasi, bengkak nyeri dan panas . (Awad et al, 2009). Kuman tersebut masuk ke dalam tubuh yang mengakibatkan berbagai manifestasi dari yang ringan seperti pengingkatan suhu tubuh sampai yang berat seperti sepsis yang dapat mengakibatkan kematian. Mikroorganisme dapat mencapai jaringan selama dilakukan pembedahan, perawatan luka, penggantian balutan, dan tindakan minor yang melibatkan luka bedah. Sedangkan penyebaran mikroorganisme tersebut dapat melalui manusia (yaitu: perawat, pasien atau setiap orang yang menyentuh luka tersebut); benda mati (yaitu: instrument, benang jahit, sprei, kain kassa dan cairan); udara (yaitu: debu, droplet udara dari orang yang membantu bedah atau yang merawat luka, serta teknik sterilisasi dan desinfeksi yang dipakai kurang tepat). Tujuan teknis aseptik adalah untuk mengurangi atau menghilangkan sejumlah mikroorganisme, baik yang terdapat pada permukaan benda hidup (kulit/jaringan) maupun yang terdapat pada permukaan benda-benda mati (alat-alat kesehatan) hingga mencapai taraf yang aman (Gruendemann, 2005).

Laparotomi merupakan pembedahan perut sampai membuka selaput perut. Sedangkan yang dimaksud pembedahan perlaparotomi adalah berbagai jenis operasi pada uterus, operasi pada tuba fallopii dan operasi 
pada ovarium. Ada empat cara pembedahan pada perut, yaitu: midline incision, paramedium, ,transverse upper abdomen incision, dan transverse lower abdomen incision. Indikasi untuk dilakukan laparotomi adalah jika terjadi trauma abdomen (baik tumpul maupun tajam), perforasi, peritonitis, perdarahan saluran pencernaan (Internal Blooding), adanyan sumbatan pada usus halus dan besar dan adanya masa pada abdomen. Komplikasi yang biasanya terjadi pada klien post laparotomi, diantaranya; infeksi luka operasi, ventilasi paru tidak adekuat, gangguan kardiovaskuler, gangguan keseimbangan cairan dan elektrolit, gangguan rasa nyaman dan injury (Arif \& Kumala, 2009).

Setiap operasi merupakan tindakan yang dapat mengancam jiwa penderita. Operasi pada dasarnya merupakan trauma yang akan menimbulkan perubahan faali sebagai respon (Sjamsuhidajat, 1997). Oleh karena itu, maka perawatan pasca bedah dinilai sangat penting karena merupakan fase pemulihan pasien (Kozier, 1991). Proses perawatan dilakukan untuk menemukan adanya kebutuhan-kebutuhan fisik dan psikologis yang ada dan memfasilitasi pasien untuk pulih (Lippincott, 1997). Seorang pasien yang masuk Rumah Sakit untuk menjalani perawatan tentu berharap mendapat kesembuhan atau perbaikan penyakitnya, setidaknya mendapat keringanan keluhannya. Namun adakalanya pasien terkena infeksi baru yang mengakibatkan penyakitnya lebih berat, lebih lama perawatannya, banyak tindakan diagnostik yang harus dilakukan serta obat yang dibutuhkan dan biaya yang meningkat.

Perawatan pasca bedah merupakan salah satu runtutan dari keperawatan perioperatif, yaitu istilah yang digunakan untuk menggambarkan tanggungjawab keperawatan yang berhubungan dengan fase-fase pre operasi, intra operasi dan pasca operasi (Capernito, 1999). Perawatan pasca bedah dimulai sejak klien selesai pembedahan dan berlanjut sampai klien selesai perawatan medis (Lewis et.all. 2000). Perawatan post laparotomi adalah bentuk pelayanan perawatan yang di berikan kepada 
pasien yang telah menjalani operasi pembedahan perut. Adapun tujuan perawatan post laparotomi, antara lain; mengurangi komplikasi akibat pembedahan, mempercepat penyembuhan, mengembalikan fungsi pasien semaksimal mungkin seperti sebelum operasi, mempertahankan konsep diri pasien, dan mempersiapkan pasien pulang.

Infeksi Rumah Sakit sering disebut sebagai Infeksi Nosokomial. Infeksi nosokomial adalah infeksi yang timbul atau terjadi sesudah 72 jam perawatan pada pasien rawat inap didapat di rumah sakit dan terjadi pada pasien yang dirawat lebih lama dari masa inkubasi suatu penyakit (Zulkarnain, Iskandar, 2006). Infeksi nosokomial dapat terjadi karena faktor kontaminasi kuman, keadaan penderita, keadaan setempat pada luka, lama perawatan sebelum operasi, dan lama operasi (Depkes RI, 1993:3). Hal ini perlu diantisipasi agar kejadian tersebut tidak dialami oleh pasien dengan melakukan perawatan secara paripurna mulai dari persiapan pre operatif dan post operatif dengan baik. Menurut Palmar (1987), persiapan yang dilakukan mulai dari pre operatif dapat mencegah infeksi luka operasi di atas $1 \%$ sadangkan intra operatif dan post operatif dapat mencegah infeksi nosokomial di bawah $1 \%$.

Infeksi post laparotomi adalah infeksi pada waktu penderita di rawat di rumah sakit tidak sedang dalam masa inkubasi dari infeksi tersebut (Kozier, et al, 1991:462). Infeksi nosokomial terjadi karena adanya interaksi antara host, agent dan environment. Ada beberapa faktor yang mempengaruhi terjadinya infeksi nosokomial, yaitu: faktor endogen seperti umur, seks, penyakit penyerta dan faktor eksogen seperti lama penderita dirawat di rumah sakit, kelompok yang merawat penderita, lingkungan, peralatan, dan teknis medis yang dilakukan (Hasbullah T, 1993:8). Infeksi nosokomial merupakan masalah yang besar di suatu Rumah Sakit, apalagi di Rumah Sakit dengan jumlah pasien yang banyak dan tenaga perawat yang sedikit. Di negara maju program pengendalian infeksi lebih baik dibandingkan dengan negara berkembang. Di Amerika Serikat dilaporkan infeksi mencapat $5 \%$ per 
tahun bahkan mungkin lebih baik dengan angka mortalitas $1 \%$ (Utji R, 1993:5).

Hasil penelitian di beberapa Rumah Sakit Amerika memperlihatkan insiden infeksi nosokomial menduduki peringkat kedua setelah infeksi saluran kemih. Datanya adalah sebagai berikut: infeksi saluran kemih: 42\%, infeksi luka operasi nosokomial: $21 \%$, infeksi saluran bagian bawah: 14\% dan bekteriemia: $5 \%$, sisanya infeksi yang lain (Beunett, 1998). Di Indonesia, data dari studi epidemiologi tentang infeksi nosokomial masih sangat sedikit. Data klinis yang berasal dari Rumah Sakit Rujukan nasional ataupun profesi menunjukan bahwa insiden nosokomial masih tergolong tinggi.

Pencegahan Infeksi Nosokomial sangat penting karena dampak dari infeksi tersebut sangat merugikan, diantaranya: proses penyembuhan luka laparotomi akan menjadi semakin lama, hospitalisasi menjadi semakin lama, biaya perawatan dan pengobatan akan meningkat serta mortalitas semakin naik. Selain itu, tingkat kepercayaan masyarakat terhadap rumah sakit akan menurun dengan tingginya angka Infeksi Nosokomial. Untuk menurunkan tingkat Infeksi Nosokomial harus dilakukan beberapa pencegahan, diantaranya; mengisolasi sumber infeksi potensial dengan barrier keperawatan, membersihkan dan melakukan desinfeksi secara efektif terhadap lingkungan fisik, mencuci tangan efektif, teknik pembalutan aseptik, dan barrier keperawatan terbalik atau isolasi protektif (Morison, Moya, 2004).

Penelitian mengenai gambaran perawatan post operasi laparotomi ini dilakukan karena berdasarkan hasil Studi Pendahuluan yang didapatkan dari Instalasi Bedah Sentral dan SIM RS , jumlah tindakan operasi laparotomi lebih banyak dilakukan daripada jumlah tindakan operasi lainnya, seperti: appendectomy. Berdasarkan data yang diperoleh, jumlah tindakan laparotomi dari bulan Januari 2016 sampai Desember 2016 sebanyak 185 orang, sedangkan jumlah tindakan appendectomy dari bulan Januari 2016 sampai Desember 2016 hanya 121 orang. Selain itu, 
data mengenai kejadian laparotomi pada tahun 2016 adalah sebanyak 0,29\% dan infeksi post laparotomi pada tahun 2016 adalah 1,81\% Angka infeksi tersebut menunjukkan angka yang cukup tinggi karena sebaiknya angka tersebut adalah dibawah $1 \%$.

Pada saat dilakukan studi pendahuluan melalui observasi dan wawancara pada perawat pelaksana dan pasien yang sedang dirawat pada di RS di wilayah Kabupaten Sumedang, pelaksanaan tindakan secara aseptik terhadap 3 (tiga) dari 5 (lima) orang pasien yang meliputi kesterilan alat, dan antiseptik meliputi: desinfeksi luka, mencuci tangan dan isolasi masih kurang diperhatikan, misalnya dalam hal mencuci tangan sebelum dan sesudah melaksanakan perawatan luka masih ada diantaranya perawat yang tidak melakukan cuci tangan terlebih dahulu, ada juga yang mencuci tangan tidak memakai antiseptik, dan dalam pelaksanaan perawatan luka sendiri masih ada perawat yang tidak menggunakan sarung tangan dan juga penggunaan pinset yang telah dipergunakan pada luka tetapi dipakai juga untuk mengambil kapas atau kasa steril di area yang steril. Sedangkan terhadap 2 pasien lainnya tindakan perawatan luka dilakukan sesuai dengan SOP (Standar Operasional Prosedur) yang mengacu pada standar Departeman Kesehatan R.I. dimana perawat mempertahankan prinsip steril, menggunakan sarung tangan, mencuci tangan dengan antiseptic serta menggunakan pinset steril untuk mengambil kassa/kapas steril.

Ruang perawatan pasca bedah memiliki SOP (Standar Operasional Prosedur) mengenai perawatan luka yang mengacu pada Panduan Perawataan Luka Departemen Kesehatan R.I tahun 1995 dan sudah disosialisasikan kepada perawat pelaksana yang berkerja di RS. Akan tetapi, pelaksanaannya terkadang tidak sesuai SOP tersebut. Banyak hal yang mempengaruhi petugas/perawat melakukan tindakan yang kurang baik, karena tindakan seseorang akan dipengaruhi oleh fasilitas, kebiasaan dan dukungan dari lingkungan sekitar, sikap dan 
Pelaksanaan perawatan luka pasca laparotomi dilakukan melalui proses perawatan yang terdiri dari 4 (empat) tahapan, yaitu: pengkajian, persiapan (klien, alat-alat dan lingkungan), pelaksanaan perawatan luka, dan evaluasi serta dokumentasi yang masing-masing saling berkesinambungan dan berkaitan satu sama lain. Perawatan luka pasca laparotomi dikatakan adekuat jika proses pengkajian, persiapan (klien, alat-alat dan lingkungan) didapat hasil lebih dari $65 \%$, dan tidak adekuat jika didapat hasil kurang atau sama dengan $65 \%$. Pelaksanaan perawatan luka pada klien pasca operasi laparotomi di RS nampak masih belum optimal/ adekuat sehubungan dengan latar belakang pendidikan dan pengalaman kerja perawat yang bervariasi dan kurang lengkapnya alat-alat atau instrument di ruangan serta dokumentasi yang kurang lengkap.

Setelah melakukan studi pendahuluan maka penelitian ini penting dilakukan untuk mengetahui bagaimana gambaran perawatan luka post laparotomi sehingga dapat dilakukan pencegahan-pencegahan untuk menurunkan angka kejadian infeksi nosokomial. Berdasarkan latar belakang di atas, maka penulis melakukan studi deskriptif mengenai perawatan Luka pada Pasien dengan infeksi Post Laparatomy di RS yang ada di Kabupaten Sumedang”.

\section{METODE}

Jenis penelitian yang digunakan dalam penelitian ini adalah penelitian deskriptif. Pada penelitian ini penulis ingin menjelaskan gambaran mengenai kondisi perawatan luka pada klien pasca laparotomi di RS Jakarta, apakah pelaksanaannya adekuat atau tidak adekuat mulai dari tahap pengkajian, persiapan (klien, alat-alat dan lingkungan), pelaksanaan, serta evaluasi dan dokumentasi. Sampel pada penelitian ini adalah 60 orang perawat dengan menggunakan metode total sampling. Instrumen yang digunakan berasal dari Pedoman Pelaksanaan Perawatan Luka Dep.Kes. R.I. tahun 1995 halaman 66-67. Jumlah instrument yang akan digunakan tergantung pada variabel yang diteliti. Pada penelitian ini variabel yang diteliti jumlahnya satu variabel dengan empat sub variabel. Pengisian instumen 
dilakukan oleh tiga orang observer. Teknik observasi menggunakan metode observasi non partisipasif. Lembar observasi akan diisi pada saat responden melakukan tindakan perawatan luka oleh observer, yaitu peneliti itu sendiri dan dua orang tim pengumpul data yang akan membantu penulis. Teknik pemilihan tim bantuan pengumpul datanya adalah dengan bekerjasama dengan pihak Rumah Sakit dengan kriteria: perawat pelaksana minimal memiliki tingkat pendidikan DIII dan memiliki pengalaman bekerja minimal 5 tahun.

Pembobotan instrument menggunakan scoring 0 dan 1 . Jumlah observasi 44 pernyataan. Kriteria scoring dari tiaptiap observasi sebagai berikut: nilai 1 jika kegiatan kritikal point dilaksanakan dan nilai 0 jika kegiatan kritikal point tidak dilaksanakan.

\section{HASIL}

Pada penelitian ini didapatkan hasil analisis univariat mengenai usia, jenis kelamin dan tingkat pendidikan dengan data sebagai berikut
Tabel 1

Distribusi frekuensi karakteristik responden

\begin{tabular}{|c|c|c|c|}
\hline Variabel & $\begin{array}{l}\text { Sub } \\
\text { variabel }\end{array}$ & $\mathrm{n}$ & $\%$ \\
\hline Jenis & Laki-laki & 17 & 28,3 \\
\hline kelamin & Perempuan & 43 & 71,7 \\
\hline \multirow[t]{2}{*}{ Masa kerja } & $\leq 10$ tahun & 18 & 30 \\
\hline & $>10$ tahun & 42 & 70 \\
\hline \multirow{2}{*}{$\begin{array}{l}\text { Tingkat } \\
\text { pendidikan }\end{array}$} & DIII & 49 & 81,7 \\
\hline & Profesi & 11 & 18,3 \\
\hline
\end{tabular}

Hasil analisa variabel pengkajian, analisa data, perencanaan pelaksanaan dan evaluasi serta dokumentasi keperawatan digambarkan melalui tabel di bawah ini:

Tabel 2

Distribusi frekuensi pelaksanaan perawatan luka pada pasien dengan infeksi post op laparatomy

\begin{tabular}{llll}
\hline Variabel & Sub variabel & $\mathrm{n}$ & $\%$ \\
\hline Pengkajian & Adekuat & 44 & 73,3 \\
\cline { 2 - 4 } & Tidak adekuat & 16 & 26,7 \\
\hline Analisa Data & Adekuat & 21 & 35 \\
\cline { 2 - 4 } & Tidak adekuat & 39 & 65 \\
\hline Perencanaan & Adekuat & 48 & 80 \\
\cline { 2 - 4 } & Tidak adekuat & 12 & 20 \\
\hline Implementasi & Adekuat & 32 & 53,3 \\
\hline Evaluasi dan & Tidak adekuat & 28 & 46,7 \\
\hline dokumentasi & Adekuat & 48 & 80 \\
\hline & & & \\
\hline
\end{tabular}

Pada penelitian ini diperoleh gambaran pelaksanaan perawatan luka, mulai dari tahap pengkajian sampai dengan tahap evaluasi. Pada 
tahap pengkajian didapatkan data 44\% adekuat melaksanakan tahapan pengkajian sesuai SOP, pada tahap analisa data didapatkan 35\% adekuat perawat membuat analisa data keperawatan, pada tahap perencanaan $48 \%$ perawat secara adekuat melakukan perencanaan keperawatan, pada tahap implementasi sebanyak $32 \%$ perawat secara adekuat melaksanakan tahapan implementasi sesuai SOP, pada tahap evaluasi dan dokumentasi sebanyak $80 \%$ perawat secara adekuat melaksanakan tahapan evaluasi dan dokumentasi sesuai SOP.

\section{PEMBAHASAN}

Fokus penelitian ini adalah untuk mengatahui gambaran yang jelas tentang pelaksanaan perawatan luka pada pasien dengan infeksi post laparotomi di RS. Luka adalah suatu kerusakan anatomi berupa diskontinuitas jaringan yang disebabkan oleh trauma dari luar (Perdanakusuma, 1998).

Laparotomi merupakan suatu tindakan pembedahan membuka abdomen dengan cara membuat sayatan, dimana tipe sayatan tersebut dapat berupa sayatan tegak lurus (vertikal), miring (diagonal) (Monahan, et. all., 1998). Pendapat yang lebih singkat dikemukakan oleh (Ahmad, 2002) bahwa laparotomi merupakan pembedahan perut, membuka selaput perut dengan operasi. Berdasarkan data dari SIM RS, tindakan operasi laparatomy dapat dilakukan atas berbagai indikasi misalnya herniotomy, operasi caesar dan operasi lainnya yang membuka jaringan perut.

Widasari (2002) mengungkapkan faktor-faktor yang mempengaruhi terjadinya infeksi pada luka pasca bedah (laparotomi) adalah karakteristik pasien, misalnya usia, nutrisi, imunologi, penyakit dan obatobatan, serta jenis perlukaan (bersih/kotor). Selain hal-hal diatas, jenis pembedahan bisa menjadi faktor risiko terjadinya infeksi nosokomial, jenis operasi cito lebih berisiko mengalami infeksi dibandingkan jenis operasi elektif. Infeksi luka operasi laparotomi, yang hampir seluruhnya merupakan infeksi nosokomial, menjadi kendala bagi kesehatan, karena menyebabkan efek bermakna pada peningkatan angka mortalitas dan morbiditas. Teknik perawatan 
luka pada klien post laparotomi yang baik akan mengurangi risiko timbulnya komplikasi terhadap pasien, tetapi apabila teknik yang dilakukan kurang baik, maka akan meningkatkan risiko timbulnya komplikasi.

Luka adalah kerusakan hubungan antar jaringan-jaringan pada kulit, mukosa membran dan tulang atau organ tubuh lain (Agung, 2005). Selain itu, menurut Koiner dan Taylan (2001), Luka adalah terganggunya integritas normal dari kulit dan jaringan di bawahnya yang terjadi secara tiba-tiba atau disengaja, tertutup atau terbuka, bersih atau terkontaminasi, superficial atau dalam. Beberapa hal yang perlu diperhatikan dalam pengertian luka seperti Klasifikasi Luka yang diklasifikasikan dalam beberapa bagian antara lain luka disengaja dan Luka tidak disengaja.

Ismail (2008) menjelaskan faktor yang mempengaruhi luka yaitu: berdasarkan usia menyatakan bahwa anak dan dewasa penyembuhan lebih cepat daripada orang tua. Orang tua lebih sering terkena penyakit kronis, penurunan fungsi hati dapat mengganggu sintesis dari faktor pembekuan darah; berdasarkan nutrisi menyatakan penyembuhan menempatkan penambahan pemakaian pada tubuh. Klien memerlukan diit kaya protein, karbohidrat, lemak, vitamin $\mathrm{C}$ dan $\mathrm{A}$, dan mineral seperti Fe, Zn. Klien kurang nutrisi memerlukan waktu untuk memperbaiki status nutrisi mereka setelah pembedahan jika mungkin. Klien yang gemuk meningkatkan resiko infeksi luka dan penyembuhan lama karena supply darah jaringan adipose tidak adekuat, berdasarkan infeksi menyatakan infeksi luka menghambat penyembuhan (Ismail, 2008).

Kondisi fisik dapat mempengaruhi penyembuhan luka. Adanya sejumlah besar lemak subkutan dan jaringan lemak (yang memiliki sedikit pembuluh darah) mengakibatkan gangguan sirkualsi dan oksigenisasi pada jaringan. Pada orang-orang yang gemuk penyembuhan luka lambat karena jaringan lemak lebih sulit menyatu, lebih mudah infeksi, dan lama untuk sembuh. Aliran darah dapat terganggu pada orang dewasa 
dan pada orang yang menderita gangguan pembuluh darah perifer, hipertensi atau diabetes millitus. Oksigenasi jaringan menurun pada orang yang menderita anemia atau gangguan pernapasan kronik pada perokok. Kurangnya volume darah akan mengakibatkan vasokonstriksi dan menurunkan ketersediaan oksigen dan nutrisi untuk penyembuhan luka; Hematoma (bekuan darah), merupakan hal yang sering terjadi, sehingga darah pada luka secara bertahap diabsorbsi oleh tubuh masuk kedalam sirkulasi.

Apabila terdapat bekuan yang besar, hal tersebut memerlukan waktu untuk dapat diabsorbsi oleh tubuh, sehingga menghambat proses penyembuhan luka; berdasarkan faktor benda asing bahwa benda asing seperti pasir atau mikroorganisme akan menyebabkan terbentuknya suatu abses sebelum benda tersebut diangkat. Abses ini timbul dari serum, fibrin, jaringan sel mati dan lekosit (sel darah putih), yang membentuk suatu cairan yang kental yang disebut dengan nanah (Ismail, 2008) Iskemia merupakan suatu keadaan dimana terdapat penurunan suplai darah pada bagian tubuh akibat dari obstruksi dari aliran darah. Hal ini dapat terjadi akibat dari balutan pada luka terlalu ketat. Dapat juga terjadi akibat faktor internal yaitu adanya obstruksi pada pembuluh darah itu sendiri; Diabetes dengan Hambatan terhadap sekresi insulin akan mengakibatkan peningkatan gula darah, nutrisi tidak dapat masuk ke dalam sel. Akibat hal tersebut juga akan terjadi penurunan protein-kalori tubuh; Keadaan luka menyatakan bahwa keadaan khusus dari luka mempengaruhi kecepatan dan efektifitas penyembuhan luka. Beberapa luka dapat gagal untuk menyatu. Beberapa diantaranya adalah penggunaan obat anti inflamasi (seperti steroid dan aspirin), dimana heparin dan anti neoplasmik mempengaruhi penyembuhan luka.

Penggunaan antibiotik yang lama dapat membuat seseorang rentan terhadap infeksi luka seperti steroid akan menurunkan mekanisme peradangan normal dan tubuh terhadap cedera, antikoagulan dapat mengakibatkan perdarahan, antibiotik dapat efektif diberikan segera sebelum pembedahan untuk bakteri penyebab kontaminasi yang spesifik. 
Jika diberikan setelah luka melaksanakan SOP perawatan luka pembedahan tertutup, tidak akan dengan adekuat.

efektif akibat koagulasi intravaskular (Ismail, 2008).

Data lain yang diperoleh dari penelitian ini adalah jumlah perawat Sotani (2009) mengungkapkan bahwa dengan latar pendidikan DIII dalam proses penyembuhan luka keperawatan sebanyak 81,7 5 dan dapat diklasifikasikan menjadi penyembuhan primer dimana luka diusahakan bertaut, biasanya dengan bantuan jahitan dan penyembuhan sekunder dimana penyembuhan luka tanpa ada bantuan dari luar perawat dengan latar belakang pendidikan Ners sebanyak 18,3\%. Hal ini juga tidak menjamin bahwa perawat DIII yang merupakan perawat vokasi dan terampil mampu melaksanakan SOP dengan adekuat. (mengandalkan antibodi).

Pada penelitian ini didapatkan data bahwa terdapat $71 \%$ perawat perempuan yang melakukan perawatan luka di instalasi bedah sentral dan 28,3\% perawat berjenis kelamin laki-laki. Perawat yang memiliki masa kerja atau pengalaman kerja lebih dari 10 tahun ada $70 \%$ dan yang masa kerjanya kurang dari 10 tahun terdapat 30\%. Berdasarkan penelitian ini meskipun mayoritas perawat memiliki masa kerja yang lama, akan tetapi tingkat kepatuhan perawat terhadap SOP tidak berjalan linear hal ini dibuktikan dengan adanya data $46,7 \%$ perawat tidak

Pada pelaksanaan pengkajian sebanyak $73,3 \%$ perawat melaksanakan SOP dengan adekuat, artinya masih ada 26,7\% perawat yang belum melaksanakan pengkajian keperawatan secara adekuat. Pengkajian dalam penelitian ini meliputi: lokasi dan letak luka, bentuk dan ukuran luka, tanda-tanda infeksi, dan mengkaji apakah ada perdarahan, pus atau bau tidak sedap.Persiapan dalam penelitian ini meliputi tiga bagian, yaitu: persiapan pasien pasca laparotomi, persiapan alat-alat steril dan tidak steril, dan lingkungan yang mendukung misalnya membatasi pengunjung, memasang sampiran (bila perlu), alat tenun dalam keadaan 
bersih dan ruangan sudah dibersihkan (Nursalam, 2003).

Pada penelitian ini didapatkan data sebanyak $35 \%$ perawat tidak melaksanakan analisa data sesuai dengan SOP. Hal ini sejalan dengan data lain yaitu jumlah perawat DIII yang dominan, hal ini terjadi dikarenakan perawat DIII merupakan perawat vokasi yang memiliki peran lebih sedikit dalam menyusun analisa data. Tahap analisa data keperawatan meliputi penyusunan data fokus (data objektif dan subjektif), menentukan diagnosa keperawatan dan menyusun prioritas diagnosa keperawatan (Nursalam, 2003).

Pada penelitian ini didapatkan data bahwa terdapat $53,3 \%$ perawat tidak menyusun perencanaan sesuai SOP, artinya $46,7 \%$ perawat tidak menyusun perencanaan sesuai SOP dengan adekuat. Data lain menunjukkan $\quad 80 \%$ perawat melaksanakan implementasi sesuai SOP, artinya masih ada $20 \%$ perawat tidak melaksanakan prosedur sesuai SOP. Pelaksanaan dalam penelitian ini mulai dari memasang perlak/ pengalas, mendekatkan bengkok, membuka plester, membuka balutan lama, mencuci tangan, memakai sarung tangan, mengambil alat steril, mencuci atau membersihkan luka, mengeringkan lukaa, membuang kapas lidi/ kassa yang kotor, menyimpan pinset dan gunting yang telah digunakan pada tempat alat yang terpisah dari alat steril, memberikan topical terapi, memberi kompres lembab, menutup luka, melepas sarung tangan, memasang plester, melakukan komunikasi, merapikan klien, membereskan alat-alat dan mencuci tangan kembali dengan benar (Potter \& Perry, 2005).

Hasil penelitian pada tahap evaluasi dan dokumentasi didapatkan data sebanyak $80 \%$ perawat melaksanakan sesuai SOP dan sebanyak $20 \%$ tidak menjalankan SOP dengan adekuat. Evaluasi dalam penelitian ini meliputi: mengamati respon pasien, menanyakan kenyamanan pasien. Sedangkan dokumentasi adalah pencatatan yang dilakukan setelah tindakan selesai dilaksanakan, meliputi: mendokumentasikan tandatanda infeksi jika ada dan proses penyembuhan atau granulasi (Potter \& Perry, 2005) 


\section{KESIMPULAN}

Hasil penelitian ini menunjukkan bahwa pada tahap pengkajian $44 \%$ perawat adekuat melaksanakan tahapan pengkajian sesuai SOP, pada tahap analisa data didapatkan 35\% perawat adekuat membuat analisa data keperawatan, pada tahap perencanaan $48 \%$ perawat secara adekuat melakukan perencanaan keperawatan, pada tahap implementasi sebanyak $32 \%$ perawat secara adekuat melaksanakan tahapan implementasi sesuai SOP, pada tahap evaluasi dan dokumentasi sebanyak $80 \%$ perawat secara adekuat melaksanakan tahapan evaluasi dan dokumentasi sesuai SOP.

Hasil penelitian ini diharapkan dapat menjadi bahan masukan bagi pihak manajemen rumah sakit untuk mengoptimalkan pelayanan keperawatan terhadap pasien dengan memfasilitasi kegiatan yang berbentuk sosialisasi dan pelatihan tentang keselamatan pasien kepada seluruh staf rumah sakit, mengevaluasi pelaksanaan standar operasional prosedur (SOP) asuhan keperawatan yang aman, mencantumkan informasi pendukung berupa poster di gedung Jamkesmas dan menyosialisasikan kepada seluruh perawat dan tenaga kesehatan lain tanpa terkecuali tentang standar keselamatan pasien yang tercakup dalam patient safety.

Hasil penelitian ini diharapkan menjadi acuan untuk perawat agar meningkatkan pengetahuan tentang keselamatan pasien dengan mengikuti sosialisasi dan pelatihan yang diselenggarakan oleh tim patient safety rumah sakit serta memberikan asuhan keperawatan sesuai dengan prinsip keselamatan pasien (patient safety) di rumah sakit. Bagi perawat yang memiliki sikap yang mendukung diharapkan bisa terus mempertahankan dan meningkatkannya untuk mewujudkan keselamatan pasien dengan sebaikbaiknya. Untuk peneliti selanjutnya diharapkan melakukan penelitian lebih lanjut mengenai faktor lain yang menyebabkan infeksi luka operasi seperti faktor nutrisi dan media penyembuhan luka. 


\section{DAFTAR PUSTAKA}

Adams J., Anderson S., Bateman H., Djonokusumo E., Hillmore R., Jackson D., Lakhani I., Lusznat S., Adam M.K., Sargeant H. (2007). Dictionary of Nursing. London. A\&C Black.

Alimul A.A., (2003). Riset Keperawatan dan Teknik Penulisan Ilmiah. Jakarta. Salemba Medika.

Arif Muttaqin dan Kumala Sari. (2009). Asuhan Keperawatan Perioperatif. Jakarta: Salemba Medika.

Arikunto, S. (2010). Prosedur Penelitian Suatu Pendekatan Praktek. Jakarta: PT Rineka Cipta.

Berger, K.J. (2000). Fundamental of Nursing: Collaborating For Optimal Health. Connecticut. $2^{\text {nd }}$ Edition. Appleton\&Lange.

Bennett. J.V. (2007). Hospital Infection. Boston. New York. Brown \& Co.

Carpenito, L.J. (1997). Rencana Asuhan Keperawatan dan Dokumentasi. Jakarta. EGC.

Fisbach F.T. (2000). Documenting Care. Philadelphia. F.A. Davis Company.

Gaffer

(1999). Pengantar Keperawatan Profesional. Jakarta. EGC
Gitarja, W. S. (2002). Penatalaksanaan Perawatan Luka dengan Pendekatan Konsep Modern. Makalah disampaikan pada pelatihan Wound dan Stoma Care ke-2 Bagi Perawat. 21-25 Mei 2005. Bandung. RSUP Dr.Hasan Sadikin Bandung.

Gruandemann, Barbara J. (2005). Keperawatan Perioperatif Volume 1. Terjemahan Oleh Brahm Pendit. Jakarta : EGC.

Ignatavicius D.D. \& Bayne M.V. (1994). Medical Surgical Nursing: A Nursing Process Approach. Philadelphia. W. B. Saunders Company

Ibrahim, C. (1986). Pengantar Konsep Keperawatan dan Teori Keperawatan. Bandung. AKPER Padjadjaran Dep.Kes R.I. Bandung.

Lewis et.all..(2000). Medical Surgical Nursing. St.Louis, USA: Mosby.

Morison, M. J. Manajemen Luka.(2004). Penerbit Buku Kedokteran EGC. Jakarta

Notoatmodjo, S. (2001). Pendekatan Praktis Metodologi Penelitian Kesehatan. Jakarta: PT Rineka Cipta.

Nursalam. (2003). Konsep \& Penerapan Metodologi Penelitian Ilmu Keperawatan. Jakarta. Salemba Medika. 
Perry. (1991). Penerapan Proses Keperawatan dan Diagnosa Keperawatan. Jakarta. EGC.

Potter and Perry. (2005). Fundamental Keperawatan. Terjemahan oleh Diah Nur,dkk. Jakarta: EGC.

Sjamsuhidajat \& Jong, de Wim. (1997). Buku Ajar Bedah. Jakarta:EGC.

Smeltzer, S. C \& Bare, B. G. (2001). Keperawatan Medical Bedah Brunner \& Suddarth. Jakarta. EGC.

Sugiyono. (2009). Metode Penelitian Kuantitatif Kualitatif dan $R \& D$. Bandung: Alfabeta.
Taylor C.L.C. \& Lemone P. (1998). Fundamental of Nursing: The Art and Science of Nursing Care. Volume I. PhiladelphiaNew York. Lippocott.

Tietjen L. (1994). Pencegahan Infeksi. Alih Bahasa Siti Dhyanti W. \& Abdul Bari Saifuddin. Cetakan I. Jakarta. PKMI

Zulkarnain, I. Buku Ajar Ilmu Penyakit Dalam. (2006). Pusat penerbitan Ilmu penyakit Dalam Fakultas Kedokterqaan Universitas Indonesia. Jakarta. 